Ann. Biol. anim. Bioch. Biophys., 1978, 18 (1), 87-98.

\title{
Tibial dyschondroplasia, a cartilage abnormality in poultry
}

\author{
B. SAUVEUR, P. MONGIN
}

Station de Recherches Avicoles, I.N.R.A.

Nouzilly 37.380 Monnaie, France.

Summary. Tibial dyschondroplasia is characterized by a calcification defect and by the presence of an abnormal mass of unvascularized cartilage in the proximal metaphysis of chick and turkey tibio tarsus. The gross appearance of the lesion shows some similarities with rickets, but the histological figures are quite different, without any modification of the proliferating zone of the epiphyseal plate. The figures of the chemical composition of abnormal cartilage and the blood parameters related to mineral metabolism both remain normal. The abnormal cartilage plug seems to result from the proliferation of prehypertrophic cells in relation to the lack of metaphyseal vascularization.

Tibial dyschondroplasia is under genetic control and can be eliminated after three generations of divergent selection. In the field, its incidence is proportional to the growth rate of the flocks and males are more sensitive than female birds. In unselected birds, tibial dyschondroplasia can be induced by feeding a purified diet containing all known nutrients ; corn and soybean meal have preventing properties. The abnormality can not be prevented by any known essential nutrient, such as minerals or vitamins. Metabolic acidosis due to ammonium chloride ingestion or only to an excess of chloride, strongly increases the defect incidence, while growth simultaneously decreases. This adverse effect of chloride can be overcome by the addition of a sufficient level of sodium and potassium into the died, restoring body weight to a normal value.

Although the tibial dyschondroplasia condition presents a clinical picture quite different from that of rickets, the possible intervention of a vitamin $D$ metabolite is discussed since it is known that metabolic acidosis impairs the renal transformation of $25-(\mathrm{OH}) \mathrm{CC}$ into $1,25-(\mathrm{OH})_{2} \mathrm{CC}$.

\section{Introduction.}

Poultry production was industrialized 40 years ago; since that fime, some pre viously unknown growth disorders have appeared which are mainly ossification defects. The very intensive selection applied to birds (chiefly chicks and turkeys) has increased this problem by enlarging the muscular parts of the body without taking into account skeletal development.

The causes of these bone maturation defects are numerous (Bräunlich, 1972 ; Sauveur, Roncin and Mongin, 1975). In such simple cases, as for example perosis control by $\mathrm{Mn}$ or choline, only one nutritional deficiency is involved. On the other hand, other symptoms do not appear to depend on any dietary deficiency ; an example is cartilage abnormalities originally described by Leach and Nesheim (1965a). Their 
origin seems to lie in an inherited bone maturation defect aggravated by dietary mineral unbalance of such elements as $\mathrm{Na}, \mathrm{K}$ and $\mathrm{Cl}$. The purpose of the present paper is to review this type of lesion and to also emphasize the role of acid-base balance in the growth of domesticated birds.

\section{Description of tibial dyschondroplasia.}

The cartilage abnormality, tibial dyschondroplasia, is a calcification defect in the proximal metaphysis of the tibio tarsus and began to cause major economic losses in the turkey and broiler industry between 1970 and 1975. This disturbance has been classified as the first non-infectious cause of leg weakness in turkeys and it also represents an important origin of leg problems in chicks and guinea-fowl (in France) as well as in ducks.

The geographical extension of chick dyschondroplasia seems to be unlimited ; it was first described at the laboratory level in the United States (Leach and Nesheim, $1965 a$ and $b$ ) and then in broiler flocks in Australia and South Africa (Hemsley, 1970), Great Britain (Laursen-Jones, 1970 ; Siller, 1970 ; Siller and Duff, 1970), western Canada (Riddel, Howell and Kaye, 1971), United States (Prasad, Hairr and Dallas, 1972), Japan (ltakura, Goto and Fujiwara, 1973) and France (personal observations, 1972, unpublished).

The original name of « cartilage abnormality » given by Leach and Nesheim (1965a) has been progressively replaced by «tibial dyschondroplasia », introduced by Siller (1970). Some other names as « osteochondrodystrophy 》 (McCapes, 1967) and « cartilage plugs » (Julian, 1973), have been given to cartilage lesions which seemed to be very similar to dychondroplasia.

Estimates of its frequency in broiler flocks lie betw een 1 and 5 p. 100 ; nevertheless, Steinke (1971) had reported an incidence of 33 to 48 p. 100. After examination of 40 broiler-growing farms with a total capacity of 2 million broilers, Prasad, Hairr and Dallas (1972) estimated that the morbidity in affected flocks was 30 to 40 p. 100. It is generally recognized that the incidence is directly related to the growth rate of the flocks.

Tibial dyschondroplasia is not always externally evident. When a flock is severely affected, varied degrees of lameness appear and increase up to slaughtering. Affected birds are reluctant to walk and sit on their hocks; they rise with difficulty when prodded, walk a few steps and immediately resume a sitting position. Such a lameness can be seen after 4 weeks of age in the chicken and after 10 weeks in the turkey. In some cases, the leg bones (mainly the tibio tarsus) show a small curvature but it is not always externally observed. The stiffle and hock joints do not swell and the footpads remain normal. The bone strength of affected birds does not generally appear to be less than that of unaffected animals of the same flock.

\section{Bone examination.}

Radiographs of the limbs show bilateral symmetric lesions appearing as defined radiolucent areas within the proximal metaphysis of the tibiotarsus and sometimes, of the tarsometatarsus. On longitudinal sections of the proximal end of the bone, 
the defect is grossly visible as a white opaque mass (fig. 1), originating under the epiphysis and spreading more or less deeply down through the metaphysis (between 2 and $10 \mathrm{~mm}$ at 4 weeks). This abnormal cartilage formation occupies all the bone width in the most severely affected birds, but it is often limited to a narrow lateral band. In older birds (Riddell, Howell and Kaye, 1971), the radiotranslucent area is replaced by a zone of sclerosis. All the authors have noted that there is very little blood vessel tunneling in the abnormal area.
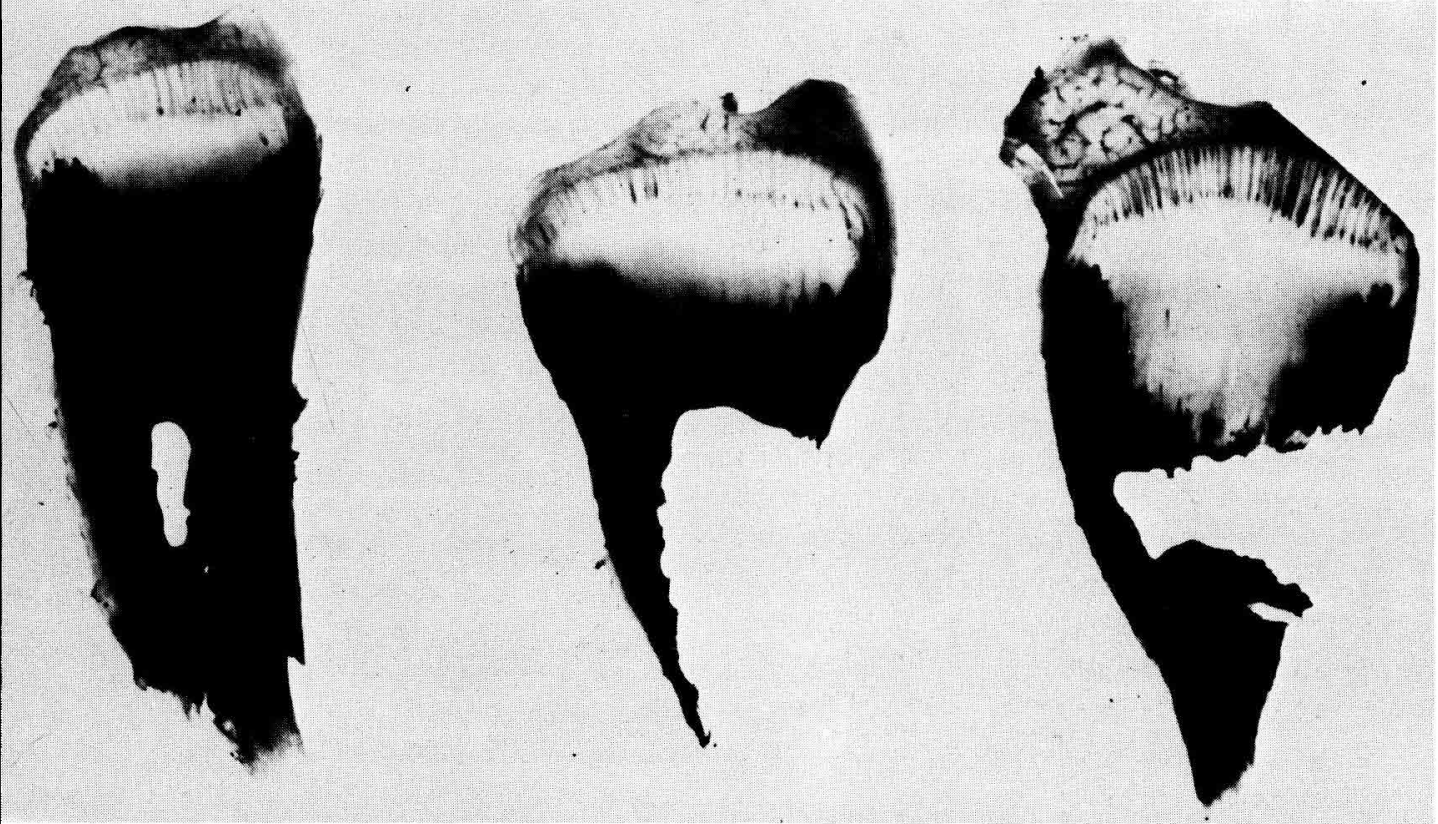

FIG. 1. - Longifudinal sections of proximal ends of tibiolarsus from 3-week old chicks showing dyschondroplosia (Sauveur, 1974, unpublished results).

\section{Histological examination.}

The gross appearance of the cartilage is similar to that observed in rickets ; however, histological examination indicates wide differences. According to the descriptions of Leach and Nesheim (1965a), Siller (1970), Itakura, Goto and Fujiwara (1973) and Riddell (1975), the dyschondroplasic cartilage can be divided into 3 parts, starting from the epiphyseal end :

- a layer of proliferating cartilage of normal constitution which may be slightly thickened or not ;

- a layer of pre-hypertrophic or hypertrophic cartilage lacking blood vessels and having a cellular structure similar to that of the normal tissue ;

- a mass of abnormal cartilage without vascular invasion in which the morphology and staining properties of the hypertrophic cells are modified; it is often difficult to differentiate the nucleus from the cytoplasm, and the cells do not fill the cavities.

For comparison, it is recalled that rickets, due to vitamin $D$ deficiency in chicks leads to an increase in the width of the proliferating zone (Belanger and Migi- 
cowski, 1958) and that EHDP $\left.{ }^{(}\right)$administration results in a proliferation of normal hypertrophic cells (Bisaz et al., 1975). According to Leach and Nesheim (1965a) the . lesions of copper deficiency described by Carlton and Henderson (1964) would be quite similar to those in dyschondroplasia.

\section{Chemical examination of abnormal cartilage.}

Leach and Nesheim (1965b) noted a small increase of the collagen content of abnormal cartilage. More recently, Lowther ef al. (1974) compared the composition of dyschondroplasic cartilage with that of normal epiphyseal growth plate cartilage and of normal articular hyaline cartilage. They concluded that proteoglycan and collagen contents of abnormal cartilage differend considerably from those of articular cartilage but were similar to those of epiphyseal growth plate cartilage of normal and dyschondroplasic birds. Moreover, the proteoglycan subunits isolated from epiphyseal growth plate cartilage of normal birds and from dyschondroplasic cartilage of afflicted animals had similar carbohydrate and protein composition. Lowther ef al. (1974) concluded that the abnormal cartilage plug arises from abnormal proliferation of the growth plate cartilage during early development. However, during in vitro incubation, abnormal cartilage slices exhibited a lower rate of proteoglycan synthesis than that recorded with epiphyseal plate cartilage; this might be a factor in the prevention of normal osteogenesis.

TABLE 1

Comparative classification of 4 types of bone abnormalities according to the associated chemical changes

(Leach and Nesheim, 1965b)

\begin{tabular}{|c|c|c|c|c|}
\hline & \multicolumn{4}{|c|}{ Type of bone abnormality } \\
\hline & $\begin{array}{c}\text { Rickets } \\
\text { (Vit. } \mathrm{D}_{3} \text { or } \mathrm{Ca} \\
\text { deficiency) }\end{array}$ & $\begin{array}{c}\text { Rickets } \\
\text { (P deficiency) }\end{array}$ & $\begin{array}{c}\text { Perosis } \\
\text { (Mn deficiency) }\end{array}$ & $\begin{array}{c}\text { Tibial } \\
\text { dyschondroplasia }\end{array}$ \\
\hline \multicolumn{5}{|l|}{ Blood } \\
\hline 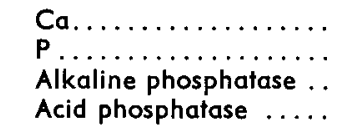 & $\begin{array}{l}-- \\
+ \\
t-+ \\
+\end{array}$ & $\frac{++}{-\frac{1}{0}}$ & $\frac{0}{--}$ & $\begin{array}{l}0 \\
0 \\
0 \\
0\end{array}$ \\
\hline $\begin{array}{l}\text { Bone ash } \ldots \ldots \ldots \ldots \ldots \\
\text { Cartilage }\end{array}$ & - & -- & 一 & - \\
\hline $\begin{array}{l}\text { Alkaline phosphatase .. } \\
\text { Mucopolysaccharide . . } \\
\text { Collagen ............. } \\
\text { Lyosomal enzymes..... } \\
\text { Width of growth plate. }\end{array}$ & $\begin{array}{c}0 \\
0 \\
+-1- \\
0 \\
+-1-\end{array}$ & $\begin{array}{c}+1-+ \\
0 \\
0 \\
0 \\
0\end{array}$ & $\begin{array}{c}-- \\
-- \\
++ \\
0\end{array}$ & $\begin{array}{r}0 \\
0 \\
+ \\
0 \\
0\end{array}$ \\
\hline
\end{tabular}

(1) EHDP = Ethane-1-hydroxy-1, 1-diphosphonate. 


\section{Associated symptoms.}

Tibial dyschondroplasia is generally characterized by the absence of other pathological signs. Soft tissues surrounding the joints are always normal; bone ash values are similar in afflicted and non-afflicted birds (Leach and Nesheim, 1965a ; Riddell, 1975). According to the same authors, calcium, phosphorus, magnesium and phosphatase levels in the blood remain unchanged. Prasad, Hairr and Dallas (1972) also found normal values for blood hematocrit and hemoglobin content. A distinction may thus be easily made between the dyschondroplasic state and some other bone abnormalities such as rickets or perosis (table 1 from Leach and Nesheim, 1965b).

\section{Causes of tibial dyschondroplasia}

According to Leach and Nesheim (1965a), it is rather unlikely that abnormal cartilage is the remains of the embryonic type of cartilage cone which can be seen in the tibial diaphysis of the one-day old chick. These authors found that the abnormal cells were morphologically different from those of the diaphyseal cartilage cone, and that fewer lesions were found at 2 weeks than at 4 weeks of age.

Siller (1970) did not agree with these hypotheses and believed that the abnormal cartilage tissue was of embryonic origin, the diaphyseal cartilage cone, which normally disappears within 2 weeks after hatching, remaining intact after this period and proliferating both longitudinally and laterally perhaps because of the defective blood supply. According to Riddell (1975), the failure of vascular invasion from the diaphysis would entail a persistence of prehypertrophic cartilage.

Whatever the exact type of maintained cartilage, Wise and Jennings (1972) also considered that the partial failure of metaphyseal blood supply, a function of which is to calcify and destroy the hypertrophic cartilage, was directly responsible for the accumulation of an uncalcified plug in the metaphysis. According to these authors, this lack of metaphyseal vascularization itself would result from abnormal pressures applied to bone epiphysis due to excessive growth rate. These authors furthermore reported that lesions of the lower ulnar were also known in dogs and pigs and that these calcification defects were thought to be caused by abnormal compression and interruption of blood supply (Riser and Shirer, 1965 ; Vaughan, 1971). Such a structural explanation of tibial dyschondroplasia is in agreement with the observed interrelationships between dyschondroplasia incidence and the growth rate of broiler flocks, and with the predominance of the lesion in male as compared to female birds. However, this hypothesis does not explain several genetic and nutritional observations discussed below.

\section{Genetic investigations.}

The original work of Leach and Nesheim (1965a) has clearly demonstrated that the susceptibility of chickens to tibial dyschondroplasia is under genetic control. The authors have developed two divergent strains in which the incidences were 40 to 50 and 15 p. 100 , respectively, after only one generation ; 6 years later Leach (1971) announced values of 80 to 90 vs 0 p. 100. It must also be noted that, contrary to what 
is seen in field observation, the low-incidence strain was heavier than the high-incidence strain. By divergent selection for three generations, Riddell $(1975,1976)$ also recently obtained two populations of broilers with dyschondroplasia incidences equal to 51 and 0 p. 100, respectively. This author noted that other skeletal defects as spondylolisthesis and twisted legs were unrelated to tibial dyschondroplasia, an observation already made by Mongin and Sauveur (1973). Steinke (1971), comparing two strains of turkeys, reported that the heavier strain had a higher incidence of tibial dyschondroplasia than the smaller strain ; the cross of the two strains was intermediate in weight and in amount of abnormal cartilage. The same observation has been made in chickens.

All the studies showed greater susceptibility of male chicks as compared to females. However, at sufficient levels to alter secondary sex characteristics, neither testosterone propionate nor diethylstilbesterol had any significant effect upon the occurrence of cartilage abnormality in male or female chicks (Leach and Nesheim, 1965a). It is thus more probable that the sex effect was due to the different growth rate.

\section{Nutritional investigations.}

In the first study of Leach and Nesheim (1965a), a 31 p. 100 incidence of tibial dyschondroplasia was found in chicks fed a purified control diet containing glucose (58.5 p. 100), isolated soybean protein $(27.00$ p. 100$)$, vitamin, mineral and amino acid mixtures, and believed to be adequate in all known nutrients; the defect was absent in chicks fed a commercial starter diet. Mixtures of chick starter with basal diet indicated that 50 to 100 p. 100 chick starter was required for complete prevention of the abnormality (table 2). During a study in which the ingredients of usual com-

TABLE 2

Effect of varying mixtures of chick starter and purified diet on the incidence of tibial dyschondroplasia

(Leach and Nesheim, 1965a)

\begin{tabular}{ccc}
\hline $\begin{array}{c}\text { Purified basal } \\
\text { diet } \\
\text { (p. 100) }\end{array}$ & $\begin{array}{c}\text { Chick starter } \\
\text { (commercial diet) } \\
\text { (p. 100) }\end{array}$ & $\begin{array}{c}\text { Incidence of tibial } \\
\text { dyschondroplasla } \\
\text { (p. 100) }\end{array}$ \\
\hline 100 & 0 & $60(20)^{*}$ \\
75 & 25 & $33(21)$ \\
50 & 50 & $14(21)$ \\
0 & 100 & $0(20)$ \\
\hline
\end{tabular}

* Number of male chicks.

mercial chick rations were added to the purified diet, only corn and soybean meal had some dyschondroplasia-preventing properties. The same study (Leach and Nesheim 1965a) showed that the abnormality was not due to a deficiency or an excess of the following nutrients in the purified diet :

- minerals : $\mathrm{Ca}, \mathrm{P}, \mathrm{Mg}, \mathrm{Fe}, \mathrm{Cu}, \mathrm{Zn}$ and $\mathrm{Se}$; 
- vitamins: $D_{3}, D_{2}$, niacin, pyridoxine and inositol. Thus, although tibial dyschondroplasia has some common visible traits with rickets or copper deficiency, its causes appear to be quite different.

Similar observations were made by Steinke (1971) in turkeys, and the following treatments were without any preventing effect :

- enhanced levels, of $\mathrm{Ca}, \mathrm{P}, \mathrm{Zn}, \mathrm{Cu}, \mathrm{Mo}$; addition of EDTA ;

- normal levels multiplied 2 to 10 times of vitamins $A, D_{3}, E, K, C, B_{2}, B_{6}, B_{12}$, panthotenic acid, niacin, choline, biotin, folacin, thiamin ;

- utilization of 4 different commercial sources of vitamin $D_{3}$, dihydrotachysterol and lumisterol ;

- some treatments such as restricted feeding, aureomycin supplementation.

These results demonstrated clearly that tibial dyschondroplasia cannot be prevented by any known nutritient. Two hypotheses were thus proposed : either an unidentified growth factor was involved, or the nutrients needed to be balanced. The second proposition appeared to be the most interesting.

Between 1970 and 1972, Mongin, Leach and Nesheim together conducted a series of experiments showing that blood acid-base balance could play a role in dyschondroplasia ; metabolic acidosis induced by feeding ammonium chloride increased dyschondroplasia incidence, even in birds fed a commercial corn-soybean diet. This fact is illustrated in table 3 (Leach and Nesheim, 1972). The incidence of dietary

TABLE 3

Effect of ammonium chloride upon incidence of tibial dyschondroplasia in an unselected strain of chicks

(Leach and Nesheim, 1972)

\begin{tabular}{|c|c|c|c|c|c|}
\hline \multirow[b]{2}{*}{ Diet } & \multirow{2}{*}{$\begin{array}{l}\text { Added } \\
\mathrm{NH}_{4} \mathrm{Cl} \\
\text { (p. 100) }\end{array}$} & \multirow{2}{*}{$\begin{array}{l}4 \text { week } \\
\text { weight } \\
\text { (g) }\end{array}$} & \multirow{2}{*}{$\begin{array}{c}\text { Incidence of } \\
\text { dyschondroplasia } \\
\text { (p. 100) }\end{array}$} & \multicolumn{2}{|c|}{ Blood composition } \\
\hline & & & & $\overline{\mathrm{pH}}$ & $\begin{array}{c}\mathrm{HCO}_{3}^{-} \\
\text {(mEq. }\end{array}$ \\
\hline Purified............ & $\begin{array}{l}0.00 \\
0.73 \\
1.46\end{array}$ & $\begin{array}{l}657 \\
575 \\
508\end{array}$ & $\begin{array}{l}20 \\
71 \\
76\end{array}$ & $\begin{array}{l}7.18 \\
7.11 \\
7.08\end{array}$ & $\begin{array}{l}18.8 \\
14.9 \\
12.2\end{array}$ \\
\hline Corn-Soybean ..... & $\begin{array}{l}0.00 \\
0.73 \\
1.46\end{array}$ & $\begin{array}{l}671 \\
667 \\
614\end{array}$ & $\begin{array}{r}0 \\
9 \\
33\end{array}$ & $\begin{array}{l}7.23 \\
7.23 \\
7.21\end{array}$ & $\begin{array}{l}21.9 \\
21.2 \\
18.6\end{array}$ \\
\hline
\end{tabular}

$\mathrm{H}^{+}$-induced dyschondroplasia could be reduced when $\mathrm{H}^{+}$ion was accompanied by anions such as sulfate or acetate, as shown in table 4 (Mongin, Leach and Nesheim, 1970 , unpublished results). These anions reduced acidosis severity in two different ways : the sulfate ion, poorly reabsorable by the renal tubule, increases urinary $\mathrm{H}^{+}$ excretion as demonstrated in laying hens by Sauveur (1969), and the metabolisable 
acetate anion consumes the $\mathrm{H}^{+}$ion during its catabolism and annuls $\mathrm{NH}_{4}^{+}$loading (Richet, Ardaillou and Amiel, 1966).

\section{TABLE 4}

Effect of anions accompanying dietary $\mathrm{H}^{+}$on tibial dyschondroplasia incidence (Mongin, Leach and Nesheim, 1970, unpublished resulîs)

\begin{tabular}{|c|c|c|c|c|}
\hline & \multirow{2}{*}{$\begin{array}{l}4 \text { week } \\
\text { weight } \\
\text { (g) }\end{array}$} & \multirow{2}{*}{$\begin{array}{c}\text { Incidence of } \\
\text { dyschondroplasia } \\
\text { (p. 100) }\end{array}$} & \multicolumn{2}{|c|}{ Blood composition } \\
\hline & & & $\mathrm{pH}$ & $\begin{array}{c}\mathrm{HCO}_{3}^{-} \\
\left(\mathrm{mEq} \cdot{ }^{-1}\right)\end{array}$ \\
\hline 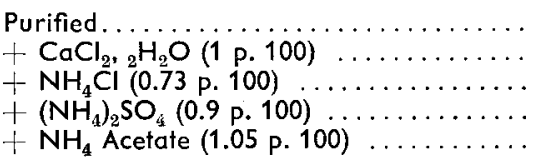 & $\begin{array}{l}661 \\
589 \\
581 \\
578 \\
658\end{array}$ & $\begin{array}{r}14.7 \\
28.1 \\
25.6 \\
18.8 \\
6.1\end{array}$ & $\begin{array}{l}7.25 \\
7.16 \\
7.17 \\
7.21 \\
7.27\end{array}$ & $\begin{array}{l}18.7 \\
15.8 \\
14.9 \\
17.0 \\
20.4\end{array}$ \\
\hline
\end{tabular}

The results of Leach and Nesheim (1972) also showed that, without any $\mathrm{H}^{+}$addition to the diet, distribution of a high chloride mineral mixture $(\mathrm{Cl}=0.84 \mathrm{p} .100$ of the dief) was sufficient to induce a very high incidence of dyschondroplasia (43 p. 100 in unselected birds and 91 p. 100 in a selected strain fed a purified diet). Similar results have been reported recently by Riddell $(1975,1976)$ with diets containing 0.75 p. 100 chloride. The problem of chloride effect upon cartilage abnormality has been studied in more detail in our laboratory. As indicated in table 5 (Sauveur and Mongin, 1974), the plasma bicarbonate decreased and dyschondroplasia incidence increased when an excess of chloride was not balanced by cation loading ( $\mathrm{Na}$ and $\mathrm{K}$ ). On the contrary, the effect of high chloride level could be strongly reduced when cations were added into the diet at a sufficient level. It also appeared that an excess of sodium relative to potassium raised dyschondroplasia incidence ; this fact was particularly obvious with the highest addition of chloride. In every case, there was good parallelism between abnormality incidence and the metabolic acidosis severity recorded.

\section{TABLE 5}

Effect of $(\mathrm{Na}+\mathrm{K})$ and $\mathrm{Cl}$ levels $(\mathrm{mEq} / 100 \mathrm{~g})$ and $\mathrm{Na} / \mathrm{K}$ ratios in the dief on tibial dyschondroplasia incidence (p. 100)

(Sauveur and Mongin, 1974)

\begin{tabular}{|c|c|c|c|c|c|c|c|c|c|c|}
\hline \multirow{2}{*}{$\mathrm{Na} / \mathrm{K}$} & \multirow{2}{*}{$\begin{array}{c}\mathrm{Cl} \text { level } \\
(\mathrm{Na}+\mathrm{K}) \text { level }\end{array}$} & \multicolumn{3}{|c|}{10} & \multicolumn{3}{|c|}{25} & \multicolumn{3}{|c|}{40} \\
\hline & & 20 & 35 & 50 & 20 & 35 & 50 & 20 & 35 & 50 \\
\hline $\begin{array}{l}1 \\
2.5 \\
0.4\end{array}$ & & 0 & $\begin{array}{c}0 \\
10 \\
7.1\end{array}$ & $\begin{array}{l}0 \\
7.6 \\
0\end{array}$ & 16.6 & 8.3 & 8.3 & 22.2 & $\begin{array}{c}17.6 \\
30.0 \\
0\end{array}$ & $\begin{array}{r}6.6 \\
16.6 \\
14.2\end{array}$ \\
\hline
\end{tabular}


It may be asked why metabolic acidosis impairs the normal cartilage maturation. It is well known that vitamine $D_{3}$ has to be transformed into 1,25 dihydroxycholecalciferol in the kidney before it becomes metabolically active (De Luca and Schnoes, 1976). Sauveur ef al. (1977) have shown both in vitro and in vivo that metabolic acidosis reduced the renal conversion of $25-(\mathrm{OH}) \mathrm{CC}$ into $1,25-(\mathrm{OH})_{2} \mathrm{CC}$ by about 40 p. 100 in rachitic chicks. The same result has been reported in rats (Lee, Russell and Avioli, 1977). It could then be supposed that vitamin $D_{3}$ metabolism was involved in dyschondroplasia, but it has been said previously that the cartilage looks different in rickets and dyschondroplasia, and it would be surprising that a defect of cholecalciferol metabolism acted only on the tibial metaphysis. Several laboratories are now investigating the direct effect of $1,25-(\mathrm{OH})_{2} \mathrm{CC}$ or $1 \alpha-(\mathrm{OH}) \mathrm{CC}$ on tibial dyschondroplasia.

The only conclusion which can be drawn today is therefore that of Leach and Nesheim (1972) : «Tibial dyschondroplasia is the result of an inherited physiological defect, the expression of which is under dietary control ». We have some data on this dietary conirol (role of chloride, anion/cation ratio), but no hypothesis which would yet explain all the recorded observations.

\section{Relationships between mineral nutrition, cartilage abnormalities and body growth}

The studies reported here are interesting, not only in relation to cartilage abnormality, but also because mineral and acid-base balance play a misappreciated role in the weight gain of domestic birds. It can be seen in table 3 that the simple utilization of a purified diet was sufficient to induce metabolic acidosis and a slight reduction of growth (Leach and Nesheim, 1972).

The equilibrium between chloride and sodium plus potassium levels in the diet is also important. Nesheim et al. (1964) have demonstrated that an excess of chloride depressed growth response of chicks unless this anion was balanced with equimolar levels of $\mathrm{Na}$ or $\mathrm{K}$ supplied by a metabolisable anion. This fact was confirmed by Mongin and Sauveur (1973) using carbonate and chloride mixtures of $\mathrm{Na}$ and $\mathrm{K}$ with a constant $\mathrm{Na} / \mathrm{K}$ ratio equal to the unity. When $\mathrm{Na}$ and $\mathrm{K}$ are not used at the same level (expressed in milliequivalents), chicks better tolerate an excess of potassium than an excess of sodium (Nesheim ef al., 1974 ; Sauveur and Mongin, 1974).

Several authors have tried to determine the exact anion/cation ratio compatible with an optimal growth; according to Melliere and Forbes (1966), it would be in the range of 1.2 to 1.8 (on a mEq basis). More recently, Hurwitz ef al. $(1973,1974)$ found that the optimal $\mathrm{Na} / \mathrm{Cl}$ ratio $(\mathrm{w} / \mathrm{w}$ ) was 1. i.e. 1.5 on a $\mathrm{mEq}$ basis. An unpublished work of Mongin and Sauveur (1973) including 24 different semisynthetic diets (3 chloride, 2 sodium and 4 potassium levels) showed (fig. 2) that the best way to get a simple relationship was to use the amount $(\mathrm{Na}+\mathrm{K}-\mathrm{Cl}$ ), expressed in $\mathrm{mEq} / 100 \mathrm{~g}$ of diet, as a variable. Under such conditions, all the experimental values of weight gain were distributed around a parabolic curve, the maximum of which was obtained for a value of $(\mathrm{Na}+\mathrm{K}-\mathrm{Cl})$ close to $25 \mathrm{mEq} / 100 \mathrm{~g}$ of diet. The same value was found again under practical conditions with 1200 8-week old broilers fed a classical 
cornsoybean diet complemented with 12 different mixtures of $\mathrm{Na}, \mathrm{K}$ and $\mathrm{Cl}$ (Sauveur and Mongin, 1974, unpublished).

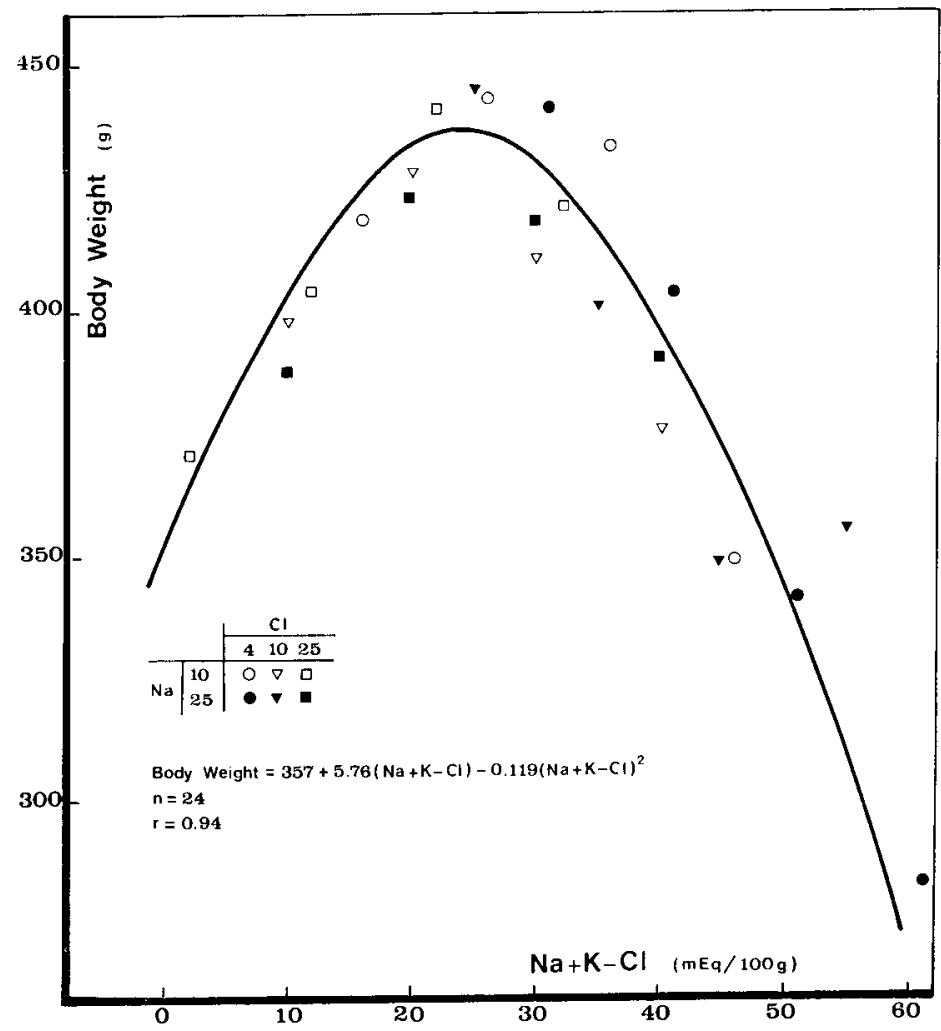

FIG. 2. - Body weight of 4-week old chicks in relation to the value of $(\mathrm{Na}+\mathrm{K}-\mathrm{Cl})$ content of the diet expressed in $\mathrm{mEq} / 100 \mathrm{~g}$ (Mongin and Sauveur, 1974, unpublished results).

In conclusion, there are strict interrelationships between $\mathrm{Na}, \mathrm{K}$ and $\mathrm{Cl}$ levels in the diet of broiler chicks, and it would be incorrect to fix the requirement for one of these minerals without knowing the levels of the other two. These observations can be particularly important when birds are fed amino acid hydrochloride mixtures.

Réunion Groupe Développement INRA/Productions animales. Montpellier, 17-18 mai 1977.

Résumé. La dyschondroplasie tibiale esł un défaut d'ossification des têtes tibiales se traduisant par la persistance d'une masse cartilagineuse non vascularisée dans la métaphyse proximale du tibiotarse des poulets et des dindons. L'apparence globale de la lésion pourrait faire penser à du rachitisme ; cependant ni l'étude histologique ni la symptomatologie générale ne confirme cette possibilité : au niveau histologique, la zone de prolifération de la plaque épiphysaire reste normale alors qu'elle est élargie dans le rachitisme ; par ailleurs ni la composition chimique du cartilage (glycoprotéines ef collagène), ni les paramètres sanguins liés au métabolisme phospho-calcique ( $\mathrm{Ca}, \mathrm{P}, \mathrm{Mg}$, phosphatase) ne 
sont significativement modifiés. L'accumulation anormale de cartilage paraît résulter d'une prolifération de cellules à l'état pré-hypertrophié en relation avec l'absence de vascularisation métaphysaire.

La sensibilité à la dyschondroplasie tibiale paraît hautement hériłable et il est possible d'éliminer totalement le trouble d'un troupeau après trois générations de sélection divergente. Sur le terrain, l'incidence est directement proportionnelle à la vitesse de croissance des troupeaux et les mâles sont toujours plus sensibles que les femelles. On peut, chez des oiseaux non sélectionnés, provoquer l'apparition de la maladie en utilisant des régimes purifiés confenant cependant tous les nutriments connus. Aucun élément minéral (macroou oligo-constituant) ni aucune vitamine n'exerce d'effet curatif contrairement au maïs et au tourteau de soja ! Une acidose métabolique due à l'ingestion de chlorure d'ammonium ou à un simple excès de chlore alimentaire, augmente fortement l'incidence de la maladie (alors que le poids vif de l'animal diminue simultanément). Cef effet nocif du chlore est supprimé par un apport simultané de sodium ef de potassium accompagnés d'un anion métabolisable.

Bien que la dyschondroplasie du poulet paraisse donc relever de mécanismes différents de ceux de rachitisme, l'intervention éventuelle d'un trouble du métabolisme de la vitamine $D$ est évoquée puisque l'on sait que l'acidose métabolique, en tant que telle, altère la synthèse rénale de $1,25-(\mathrm{OH})_{2} \mathrm{CC}$ à partir du $25-(\mathrm{OH}) \mathrm{CC}$.

\section{References}

BELANGER L. F., MIGICOWSKI B. B., 1958. Early changes of the epiphysis of rachitic chick following administration of vitamin D. J. exp. Med., 107, 821-828.

BISAZ S., SCHENK R., KUNIN A. S., RUSSELL R. G. G., MÜLHBAUER R., FLEISCH H., 1975. The comparative effects of vitamin $D$ efficiency and ethane. 1-hydroxyl-1, 1-diphosphonate administration on the histology and glycolysis of chick epiphyseal and articular cartilage. Calcif. Tiss. Res., 19, 139-152.

BRÄUNLICH K., 1972. Leg lesions in puultry. Inf. Serv. Roche no 1379, F. Hoffmann-La-Roche \& Co, Basel (Switzerland) 40 pp.

CARLTON W. W., HENDERSON W., 1964. Skeletal lesions in experimental copper deficiency in chickens. Avian Dis., 8, 48.

DE LUCA H. F., SCHNOES H. K., 1976. Metabolism and mechanism of action of vitamin D. Annu. Rev. Biochem., 45, 631-666.

HEMSLEY L. A., 1970. A cartilage abnormality of broiler chickens. Vet. Rec., 86, 385.

HURWITZ S., COHEN I., BAR A., BORNSTEIN S., 1973. Sodium and chloride requirement of the chick : relationship to acid-base balance. Poult. Sci., 52, 903-909.

HUTWITZ S., COHEN I., BAR A., MINKOV U., 1974. Sodium and chloride requirements of the 7-9 week-old broiler. Poult. Sci., 53, 326-331.

ITAKURA C., GOTO M., FUJIWARA Y., 1973. Tibial dyschondroplasia in broiler chickens in Japan. Jop. J. vet. Sci., 35, 289-297.

JULIAN R. J., 1973. Leg problems in broilers. Poult. Digest., avril 1973, 157.

LAURSEN-JONES A. P., 1970. A cartilage abnormality of broiler chickens. Vet. Rec., 86, 445.

LEACH R. M., 1971. Studies on a cartilage abnormality in young chickens. Symp. on Leg weakness in Turkeys, Nał. Turkey Faj., lowa St. Univ., Ames, USA, 37-38.

LEACH R. M., NESHEIM M. C., 1965a. Nutritional, genetic and morphological studies of an abnormal cartilage formation in young chicks. J. Nutr. 86, 236-244.

LEACH R. M., NESHEIM M. C., 1965b. Further studies of a cartilage malformation in young chicks. Proc. Cornell Nutr. Conf., 38-41.

LEACH R. M., NESHEIM M. C., 1972. Further studies on tibial dyschcondroplasia (cartilage abnormality) in young chicks. J. Nutr. 102, 1673-1680.

LEE S. W., RUSSELL J., AVIOLI L. V., 1977. 25-hydroxycholecalciferol to 1.25-dihydroxycholecalciferol : conversion impaired by systemic metabolic acidosis. Science, 195, 994-996.

LOWTHER D. A., ROBINSON H. C., DOLMAN J. W., THOMAS K. W., 1974. Cartilage matrix components in chickens with tibial dyschondroplasia. J. Nutr., 104, 922-929. 
MCCAPES R. H., 1967. Lameness in turkeys due to faulty bone formation. Anim. Nutr. Health, 22, 17.

MELLIERE A. L., FORBES R. M., 1966. Effect of altering the dietary cation-anion ratio on food consumption and growth of young chicks. J. Nutr., 90, 310-314.

MONGIN P., SAUVEUR B., 1973. Effet des teneurs en chlore, sodium et potassium du régime sur la croissance du poulet et l'apparition des anomalies cartilagineuses. Journées Rech. Avic. Cunic., Paris 1973, I. T. A. V. I. édit., Paris, 187-192.

NESHEIM M. C., LEACH R. M., ZEIGLER T. R., SERAFIN J. A., 1964. Interrelationships between dietary levels of sojium, chlorine and polassium. J. Nutr., 84, 361-366.

PRASAD S., HAIRR W. T., DALLAS J. T., 1972. Observations of abnormal cartilage formation associated with leg weakness in commercial broilers. Avian Dis., 16, 457-461.

RICHET G., ARDAILLOU R., AMIEL C., 1966 . Les sources alimentaires d'ions $\mathrm{H}^{+}$. Bases physiologiques d'une diététique de l'acidose rénale. Actualités néphrologiques de l'Hôpiłal Necker, Ed. Med. Flammarion, Paris, 207-221.

RIDDELL C., 1975. The development of tibial dyschondroplasia in broiler chickens. Avian Dis., 19, 443-462.

RIDDELL C., 1976. Selection of broiler chickens for a high and low incidence of tibial dyschondroplasia with observations on spontylolisthesis and twisted legs (perosis). Poult. Sci., 55, 145-151.

RIDDELL C., HOWELL J., KAYE M. M., 1971. Tibial dyschondroplasia in broiler chickens in western Canada. Avian Dis., 15, 557-565.

RISER W. H., SHIRER J. F., 1965. J. am. vet. Rad. Soc., 6, 50. Quoted by WISE and JENNINGS, 1972.

SAUVEUR B., 1969. Acidoses métaboliques expérimentales chez la poule pondeuse. I. Action sur l'équilibre acido-basique ef l'excrétion rénale des électrolytes. Ann. Biol. anim. Bioch. Biophys., 9, 379-391.

SAUVEUR B., GARABEDIAN M., FELLOT C., MONGIN P., BALSAN S., 1977. The effect of induced metabolic acidosis on vitamin $D_{3}$ metabolism in rachitic chicks. Calcif. Tiss. Res., 22, 121 124.

SAUVEUR B., MONGIN P., 1974. Influence of dietary level of chloride, sodium and potassium on chick cartilage abnormalities. Proc. 15th WId Poultry Congr., New-Orleans, 180-181.

SAUVEUR B., RONCIN J., MONGIN P., 1975. Troubles osseux et articulaires des pattes chez les volailles. Doc. Roche no 1357, Hofímann-La-Roche et Cie, Neuilly sur Seine (France), 44 pp.

SILLER W. G., 1970. Tibial dyschondroplasia in the fowl. J. Pathol., 101, 39-46.

SILLER W. G., DUFF R. M., 1970. Cartilage abnormality in broiler fowls. Vet. Rec., 86, 757.

STEINKE F. H., 1971. Osteodystrophy. Nutritional and related factors. Symp. on leg weakness in turkeys, Nat. Turkey Fed., lowa St. Univ., Ames, 30-36.

VAUGHAN L. C., 1971. Ver. Rec., 89, 81. Quoted by WISE and JENNINGS, 1972.

WISE D. R., JENNINGS A. R., 1972. Dyschondroplasia in domestic poultry. Vet. Rec., 91, 285-286. 